\title{
GAMBARAN PROSES PEMBERIAN UMPAN BALIK PADA PROGRAM STUDI PENDIDIKAN DOKTER FAKULTAS KEDOKTERAN UNIVERSITAS ABULYATAMA
}

\author{
Ade Kiki Riezky¹, Syarifah Nora Andriaty'1, Cut Gibdi Suji² \\ ${ }^{1}$ Departemen IImu Pendidikan Kedokteran Fakultas Kedokteran Universitas \\ Abulyatama \\ 2Program Studi Pendidikan Dokter, Fakultas Kedokteran Universitas Abulyatama
}

\begin{abstract}
An Overview of Giving Feedback Process in The Medical Education Program, Faculty of Medicine, Universitas Abulyatama. Feedback can increase student motivation to learn, therefore feedback needs to be introduced from an early learning. Feedback can also help students achieve learning goals and make students aware of their lack of knowledge so that they can improve their performance. Feedback is very helpful for lecturers to ensure the achievement of learning goals. The purpose of this study was to see an overview of the opportunities and time allocation for providing feedback between pre-clinic lecturers and clinical lecturers in the Medical Education Study Program of the Faculty of Medicine, Universitas Abulyatama. This study used a cross sectional design. The sample consisted of 40 pre-clinical and 35 clinical lecturers. The data were collected by distributing questionnaires to respondents. Based on the results of the study, it can be seen that the pre-clinical lecturers have sufficient opportunity to provide feedback $(85 \%)$, while clinical lecturers dominate the less category $(77.1 \%)$. Observation of the time allocation for giving feedback shows that the majority of pre-clinical lecturers also have a sufficient time allocation (95\% of respondents) when providing feedback, while all clinical lecturers feel that they do not have sufficient time allocation (100\%).
\end{abstract}

Keywords: Feedback, Pre-Clinical Medical Educator, Clinical Medical Educator

\begin{abstract}
Abstrak: Gambaran Proses Pemberian Umpan Balik Pada Program Studi Pendidikan Dokter Fakultas Kedokteran Universitas Abulyatama. Umpan balik dapat meningkatkan motivasi belajar mahasiswa, oleh karena itu umpan balik perlu diperkenalkan sejak dini. Umpan balik juga dapat membantu mahasiswa mencapai sasaran pembelajaran dan membuat mahasiswa menyadari kekurangan pengetahuannya sehingga dapat memperbaiki performanya. Umpan balik sangat membantu dosen untuk menjamin pencapaian sasaran pembelajaran. Tujuan penelitian ini adalah untuk melihat gambaran kesempatan dan alokasi waktu pemberian umpan balik antara dosen pre-klinik dan dosen klinik pada Program Studi Pendidikan Dokter Fakultas Kedokteran Universitas Abulyatama. Penelitian ini menggunakan desain cross sectional. Sampel pada penelitian ini terdiri dari 40 orang dosen pre-klinik dan 35 orang dosen klinik. Data diambil dengan menyebarkan kuesioner kepada responden. Berdasarkan hasil penelitian dapat dilihat gambaran bahwa dosen pre-klinik memiliki kesempatan yang cukup dalam memberikan umpan balik $(85 \%)$, sedangkan dosen klinik mendominasi kategori kurang sebanyak (77,1\%). Pengamatan alokasi waktu pemberian umpan balik menunjukan bahwa sebagian besar dosen pre-klinik juga memiliki alokasi waktu yang cukup (95\% responden) ketika memberikan umpan balik, sedangkan seluruh dosen klinik merasa tidak memiliki alokasi waktu yang cukup (100\%).
\end{abstract}

Kata kunci: Umpan balik, dosen pre-klinik, dosen klinik 
PENDAHULUAN

Umpan

meningkatkan

balik

dapat

motivasi belajar

mahasiswa, oleh karena itu umpan

balik perlu diperkenalkan sejak dini (Wood, 2007). Umpan balik juga dapat membantu mahasiswa mencapai sasaran pembelajaran dan membuat mahasiswa menyadari kekurangan pengetahuannya sehingga dapat memperbaiki performanya. Umpan balik sangat membantu dosen untuk menjamin pencapaian sasaran pembelajaran (Perera et al, 2008; Dent \& Harden, 2009).

Beberapa penelitian sebelumnya mengenai persepsi mahasiswa terhadap umpan balik, menunjukan rasa tidak puas terhadap umpan balik yang diberikan oleh dosen. Keadaan ini disebabkan oleh umpan balik yang diberikan tidak efektif sehingga tidak bermanfaat bagi mahasiswa dan tidak dapat meningkatkan performanya. Faktor penyebab ketidakpuasan mahasiswa antara lain umpan balik yang diberikan tidak sesuai dengan yang diharapkan, dosen kurang memiliki pengetahuan terhadap cara menyampaikan umpan balik (Perera et al, 2008; Dent \& Harden, 2009; Boehler et al, 2006; Blatt et al, 2008; Beaumont et al, 2008). Analisis verbal menunjukan bahwa percakapan umpan balik yang terjadi antara dosen dan mahasiswa masih bersifat satu arah yaitu fokus pada staf pengajar. Dosen juga lebih banyak memberikan pernyataan positif atau netral (You \& Trowbridge, 2009).

Penelitian umpan balik lainnya terhadap proses umpan balik yang diberikan oleh dokter bedah kepada residennya menunjukan bahwa hampir $90 \%$ dokter bedah merasa telah memberikan umpan balik dengan baik, tetapi hanya $17 \%$ residen yang setuju dengan pendapat dokter bedah (Van de Ridder, Stocking \& McGaghie, 2008). Mahasiswa dapat melakukan kesalahan yang berkelanjutan jika tidak mendapatkan umpan balik yang benar. Pemberian umpan balik pada tahap preklinik berguna untuk meningkatkan pengetahuan, keterampilan klinik dan memperbaiki perilaku mahasiswa. Komponen ini sangat bermanfaat bagi mahasiswa sebagai persiapan lanjutan ke tahap klinik (Wangou \& Doda, 2012).

Peran dosen pada pendidikan kedokteran antara lain sebagai nara sumber pada kuliah dalam kelas dan pendidikan klinik, sebagai role model dalam pekerjaan dan dalam pendidikan, sebagai fasilitator dan mentor, sebagai evaluator bagi mahasiswa dan kurikulum, sebagai perencana kurikulum dan pengajaran, serta sebagai kreator pembelajaran dan membuat panduan bagi mahasiswa (Rika, 2019).

Tujuan penelitian ini adalah untuk melihat gambaran kesempatan dan alokasi waktu pemberian umpan balik antara dosen pre-klinik dan dosen klinik pada Program Studi Pendidikan Dokter Fakultas Kedokteran Universitas Abulyatama (PSPD FK Unaya).

\section{METODE}

Penelitian ini menggunakan desain cross sectional. Pengumpulan data dilakukan dari bulan Febuari - Juni 2020 di PSPD FK Unaya dan Rumah Sakit Umum Daerah Meuraxa sebagai Rumah Sakit Pendidikan Utama. Sampel pada penelitian ini terdiri dari 40 orang dosen pre-klinik dan 35 orang dosen klinik. Data diambil dengan menyebarkan kuesioner kepada responden.

\section{HASIL}

Hasil penelitian didapatkan gambaran perbandingan kesempatan memberikan umpan balik antara dosen preklinik dan dosen klinik, serta gambaran perbandingan alokasi waktu pemberian umpan balik. 
Tabel 1. Pemberian Umpan Balik Dosen Pre-Klinik

\begin{tabular}{lcc}
\hline \multicolumn{1}{c}{$\begin{array}{c}\text { Pemberian Umpan } \\
\text { Balik }\end{array}$} & $\mathbf{N}$ & \% \\
\hline Kurang & 6 & 15 \\
Cukup & 34 & 85 \\
Baik & 0 & 0 \\
Total & 40 & 100 \\
\hline
\end{tabular}

Berdasarkan tabel 1 dapat dilihat bahwa persepsi dosen preklinik terhadap kesempatan memberikan umpan balik didominasi pada kategori cukup sebanyak 34 orang (85\%), kemudian kategori kurang sebanyak 6 orang $(15 \%)$ dan kategori baik tidak ada responden.

Tabel 2. Pemberian Umpan Balik Dosen Klinik

\begin{tabular}{lcc}
\hline \multicolumn{1}{c}{$\begin{array}{c}\text { Pemberian Umpan } \\
\text { Balik }\end{array}$} & N & \% \\
\hline Kurang & 27 & 77.1 \\
Cukup & 8 & 22.9 \\
Baik & 0 & 0 \\
Total & 35 & 100 \\
\hline
\end{tabular}

Berdasarkan tabel 2 dapat dilihat bahwa persepsi dosen klinik terhadap kesempatan memberikan umpan balik didominasi pada kategori kurang sebanyak 27 responden $(77,1 \%)$, kategori cukup 8 orang $(22,9 \%)$ dan kategori baik tidak ada responden.

Tabel 3. Distribusi Alokasi Waktu Dosen Pre-Klinik Dalam Memberikan Umpan Balik

\begin{tabular}{lcc}
\hline \multicolumn{1}{c}{ Alokasi Waktu } & N & \% \\
\hline Tidak Cukup & 2 & 5 \\
Cukup & 38 & 95 \\
Total & 40 & 100 \\
\hline
\end{tabular}

Berdasarkan tabel 3 diketahui bahwa sebagian besar dosen preklinik memiliki waktu yang cukup untuk memberikan umpan balik kepada mahasiswa, yaitu sebanyak 38 orang $(95 \%)$, sedangkan kategori tidak cukup sebanyak 2 orang $(5 \%)$.

Tabel 4. Distribusi Alokasi Waktu Dosen Klinik Dalam Memberikan Umpan Balik

\begin{tabular}{lcc}
\hline \multicolumn{1}{c}{ Alokasi Waktu } & N & \% \\
\hline Tidak Cukup & 35 & 100 \\
Cukup & 0 & 0 \\
Total & 35 & 100 \\
\hline
\end{tabular}

Berdasarkan tabel 4 diketahui bahwa seluruh dosen klinik yang berjumlah 35 orang $(100 \%)$ merasa

\section{PEMBAHASAN}

Berdasarkan hasil penelitian dapat dilihat gambaran bahwa dosen preklinik memiliki kesempatan yang cukup dalam memberikan umpan balik tidak memiliki cukup waktu untuk memberikan umpan balik.

(85\%), sedangkan dosen klinik mendominasi kategori kurang sebanyak $(77,1 \%)$. Faktor yang mempengaruhi kesempatan pemberian umpan balik ini 
antara lain adalah waktu pemberian umpan balik yang tidak cukup, tingkat pemahaman dosen terhadap materi pembelajaran dan rasa kepedulian terhadap proses pembelajaran (Riezky, 2014).

Dosen sering merasa bahwa telah memberikan umpan balik yang cukup, sementar mahasiswa merasa belum diberikan umpan balik (Bhattarai, 2007). Dosen harus dapat melakukan refleksi diri sehingga dapat mengetahui kelemahan dan kelebihan dirinya sehingga dapat memberikan umpan balik dengan baik. Kemampuan pemberian umpan balik dosen berperan penting dalam memfasilitasi mahasiswa mencapai tujuan pembelajaran (Cantillon \& Wood, 2010).

Pengamatan alokasi waktu pemberian umpan balik menunjukan bahwa sebagian besar dosen pre-klinik juga memiliki alokasi waktu yang cukup (95\% responden) ketika memberikan umpan balik, sedangkan seluruh dosen klinik merasa tidak memiliki alokasi waktu yang cukup (100\%). Waktu sering kali menjadi tantangan bagi dosen klinik dikarenakan dokter harus membagi waktu memberikan pelayanan kepada pasien dan kebutuhan pembelajaran mahasiswa. Dosen klinis lebih fokus pada pelayanan keselamatan pasien sehingga kepentingan pembelajaran terkesan diabaikan (Sulistiawati, 2018).

Seorang pendidik klinik memiliki empat role/peran yaitu sebagai dokter, sebagai guru, sebagai supervisor dan sebagai supporter. Sebagai dokter, pendidik klinis harus kompeten dalam ilmu yang dikuasainya, memiliki rasa empati kepada pasien, dan menunjukkan perilaku profesional. Dosen pendidik klinis harus memiliki ketertarikan untuk mengajar, meluangkan waktu untuk mengajar, dapat menjawab dan menjelaskan pertanyaan serta memiliki waktu untuk mengajar. Sebagai supervisor, dosen pendidik klinis memiliki kemampuan untuk memberikan arahan dan umpan balik, melimpahkan tanggung jawab, dan melibatkan mahasiswa dalam pelayanan pasien. Sebagai supporter, pendidik klinik memiliki sifat ramah, memberi bantuan, perhatian, menghargai mahasiswa sebagai individu dan memiliki sikap positif kepada pasien. Selain role yang harus dijalankan, dosen pendidik klinik juga wajib memiliki kompetensi (Sulistiawati, 2018). Srinivasan membagi kompetensi yang harus dimiliki seorang medical educator menjadi 6 kompetensi utama dan 4 kompetensi khusus. Salah satu peran utama medical educator adalah sebagai dosen pendidik klinik (Srinivasan, 2011).

Adapun kompetensi yang harus dimiliki seorang dosen pendidik klinik adalah enam kompetensi utama dan dua kompetensi khusus. Kompetensi utama yaitu medical knowledge, learner centered, keterampilan interpersonal/ komunikasi, profesionalisme, practice base reflection (self-assessment dan lifelong learning), dan system based practice (memanfaatkan sumberdaya untuk memberikan pengajaran yang optimal). Kompetensi khusus yang diperlukan sebagai pembimbing klinik yaitu membuat kurikulum dan implementasinya serta kemampuan mentorship (Sulistiawati, 2018).

\section{KESIMPULAN}

Berdasarkan hasil penelitian dapat dilihat gambaran bahwa dosen preklinik memiliki kesempatan yang cukup dalam memberikan umpan balik (85\%), sedangkan dosen klinik mendominasi kategori kurang sebanyak (77,1\%). Pengamatan alokasi waktu pemberian umpan balik menunjukan bahwa sebagian besar dosen pre-klinik juga memiliki alokasi waktu yang cukup (95\% responden) ketika memberikan umpan balik, sedangkan seluruh dosen klinik merasa tidak memiliki alokasi waktu yang cukup (100\%).

\section{SARAN}

Keterbatasan penelitian ini yaitu hanya mengamati 2 variabel dalam pemberian umpan balik. Peneliti selanjutnya disarankan dapat menambah variabel lainnya seperti kemampuan dosen dalam memberikan 
umpan balik dan jenis umpan balik yang diberikan. Peneliti selanjutnya juga dapat menganalisis hubungan tiap variabelnya.

\section{DAFTAR PUSTAKA}

Beaumont C, O'Doherty M, Shannon, L. (2008). Staff and Student Perception of Feedback

Quality In The Context of Widening Participation. York: Higher Education Academy

Bhattarai MD. (2007). ABCDEFG ISThe Principle of Constructing Feedback. J Nepal Med Association 46(167): 151-156

Blatt B, Confessore S, Kallenberg G, Greenberg L. (2008). Verbal Interaction Analysis:

Viewing Feedback Through a Different Lens. Teaching and Learning in Medicine 20(4): 329333

Boehler ML, Rogers DA, Schwind CJ, Mayforth R, Quin J, Williams RG, et al. (2006). An

Investigation of medical student reactions to feedback: a randomized controlled trial. Medical Education 40: 746-749

Cantillon P, Wood D. (2010). ABC Learning and Teaching In Medicine, Second Edition.

West Sussex: A John Wiley\& Sons Ltd

Dent JA, Harden RM. (2009). A Practical Guide Medical Teachers, Third Edition. China:

Churchill Livingstone

Perera J, Lee N, Win K, Wijesurya L. (2008). Formative Feedback to Student; The Mismatch

Between Faculty Perceptions and Student Expectations. Medical Teacher 30:395-399

Riezky AK. (2014). Proses Umpan Balik Diskusi Problem Based Learning Pada Mahasiswa

Pra KLinik di Fakultas Kedokteran Universitas Abulyatama: Suatu Pendekatan Kualitatif. [Tesis]. Jakarta: Program Studi Pendidikan Kedokteran Universitas Indonesia.
Rika Lisiswanti. (2019). Peranan Dosen Pendidikan Kedokteran: Dari Perspektif Ilmu

Pendidikan Kedokteran. JK Unila 3:186-90.

Srinivasan M, Li ST, Meyers FJ, Pratt DD, Collins JB, Braddock C, et al. (2011). Teaching as Competency: Competencies for Medical Educator. Acad Med 86(10): 1211-20.

Sulistiawati. (2018). Dosen Pendidik Klinis. Jurnal Kedokteran Mulawarman 5(2): 59-68.

Van de Ridder JM, Stocking KM, McGaghie WC, Cate OTJ. (2008). What Is Feedback in

Clinical Education?. Medical Education 42: 189-197.

Wangou H, Doda V. Peran Umpan Balik bagi mahasiswa Kedokteran. (2012). Jurnal

Pendidikan Kedokteran Indonesia 1(13): 151-158.

Wood D. (2007). Formative Assessment. United Kingdom: Association for the Study of Medical Education.

You RGB, Trowbridge RL. (2009). Why Medical Education May Be Falling at Feedback.

JAMA 302 (12): 1330-1331. 